\title{
Relationship Between Prevalence of Opisthorchiasis and Incidence of COVID-19: An Observation
}

\author{
Opisthorchiasis Prevalansı ile COVID-19 Insidansı Arasındaki İlişki: Bir \\ Gözlem
}

\author{
(D) Rujittika Mungmunpuntipantip ${ }^{1}$, (1) Viroj Wiwanitkit ${ }^{2}$ \\ ${ }^{1}$ Private Academic Consultant, Bangkok Thailand \\ ${ }^{2}$ Dr DY Patil University, Pune, India
}

Cite this article as: Mungmunpuntipantip R, Wiwanitkit V. Relationship Between Prevalence of Opisthorchiasis and Incidence of COVID-19: An Observation. Turkiye Parazitol Derg 2021;45(3):230.

\section{Dear Editor,}

Parasitic infestation is a common public health in developing country. In tropical country, there is a high incidence of intestinal parasitic disease. In Indochina, the highest incidence of opisthorchiasis is reported (1). This infection is associated with cholangiocarcinogensis and becomes important local problem. The interrelationship between opisthorchiasis and other infection is an interesting issue.Here, the authors would like to share preliminary data from the area with extremely high incidence of opisthorchiasis, Thailand. The local data showed that there is a lower incidence of Coronavirus disease-2019 (COVID-19) in the area with higher prevalence of opisihorchiasis (Table 1 ). The clinical relationship between parasitic disease and COVID-19 is little mentioned. In this report, the observation trend is interesting. An underlying pathophysiological process that might cause protective effect against active severe COVID-19 in opisthorchiasis is thioredoxin reductase-1 generating from parasite (2). This bioselenoprotien has

Table 1. Incidence of COVID-19 and prevalence of opisthorchiasis in different regions (data on December 2020)

\begin{tabular}{|l|l|l|}
\hline Region & $\begin{array}{l}\text { COVID-19 } \\
\text { incidence }\end{array}$ & $\begin{array}{l}\text { Prevalence of } \\
\text { opisthorchiasis } \\
\text { (\%) }\end{array}$ \\
\hline $\begin{array}{l}\text { Northeastern } \\
\text { Northern }\end{array}$ & 124 & $18.6 \%$ \\
Southern & 201 & $10 \%$ \\
Central & 758 & $5 \%$ \\
\multicolumn{2}{|l|}{ COVID-19: Coronavirus disease-2019 } \\
\hline
\end{tabular}

an anti-inflammatory effect and is useful for survival of virus in biliary tract (2) and the anti-inflammatory property might be protective against pathological inflammation process in COVID-19.

Keywords: Opisthorchiasis, COVID-19, incidence Anahtar Kelimeler: Opisthorchiasis, COVID-19, incidence

\section{* Ethics}

Peer-review: Internally peer-reviewed.

\section{* Authorship Contributions}

Surgical and Medical Practices: R.M., V.W., Concept: R.M., V.W., Design: R.M., V.W., Data Collection or Processing: R.M., V.W., Analysis or Interpretation: R.M., V.W., Literature Search: R.M., V.W., Writing: R.M., V.W.

Conflict of Interest: No conflict of interest was declared by the authors.

Financial Disclosure: The authors declared that this study received no financial support.

\section{REFERENCES}

1. Kamsa-Ard S, Luvira V, Suwanrungruang K, Kamsa-Ard S, Luvira V, Santong C, et al. Cholangiocarcinoma Trends, Incidence, and Relative Survival in Khon Kaen, Thailand From 1989 Through 2013: A Population-Based Cancer Registry Study. J Epidemiol 2019; 29: 197-204.

2. Suttiprapa S, Loukas A, Laha T, Wongkham S, Kaewkes $S$, Gaze $S$, et al. Characterization of the antioxidant enzyme, thioredoxin peroxidase, from the carcinogenic human liver fluke, Opisthorchis viverrini. Mol Biochem Parasitol 2008; 160: 116-22. 